УДК 342.5(ЄC)

DOI https://doi.org/10.51989/NUL.2021.4.18

\title{
ДЕЦЕНТРАЛІЗАЦІЯ ТА МОДЕЛІ МІСЦЕВОГО УПРАВЛІННЯ В ДЕРЖАВАХ - ЧЛЕНАХ ЄС
}

\section{Стогова Ольга Володимирівна,}

кандидат політичних наук, доцент, доцент кафедри фундаментальної юриспруденції та конституційного права Сумського державного університету

Автор аналізує основні моделі місцевого управління в країнах-членах ЄС та вплив децентралізації на їх еволюцію. Централізована модель найчастіше реалізується в невеликих за територією країнах та базується на визначальній ролі центрального уряду та його відомств. у цій моделі місцеві та регіональні органи управління мають обмежені компетенції в галузі регіонального розвитку та планування. Така модель реалізується в невеликих державахчленах Європейського Союзу, насамперед у країнах, які мають однорівневу систему місцевого самоврядування. Зроблено висновок, що модель місцевого управління визначається розміром країни та системою регіонального розвитку. Виділяють централізовані, децентралізовані та федеральні моделі. У статті проаналізовано основні елементи адміністративного управління регіональним плануванням та розвитком у централізованих та децентралізованих державах. У нових державах-членах ЄС централізована модель $\epsilon$ домінуючою через менший розмір країн та значну роль фондів ЄС у регіональному розвитку. Розподіл цих ресурсів контролюється центральним урядом та його відомствами, але в кількох країнах сформовані спеціальні гібридні органи. Таким чином, децентралізація в невеликих за розмірами державах стимулювалася коштами фондів ЄС. Після кризи 2008 року в управлінні регіональним розвитком запанували нові підходи: централізація та концентрація. Ці тенденції можна спостерігати в централізованих системах, які раніше частково децентралізували регіональний розвиток. Так, регіональні органи та агенції було скасовано, у регіоналізованих країнах регіональні одиниці було об'єднано, а тенденції федералізації було призупинено. У нових державах-членах та в середземноморських країнах вплив законодавства Європейського Союзу є більш значним, оскільки їхні регіональні одиниці переважно менш розвинені та є основними одержувачами коштів фондів ЄC.

Ключові слова: децентралізація, місцеве управління, моделі місцевого управління, Європейський Союз.

\section{Stohova Olga. Decentralization and models of local governance in EU member states}

The author analyzes the main models of local government in EU member states and the impact of decentralization on their evolution. The centralized model is most often implemented in small countries and is based on the defining role of the central government and its departments. In this model, local and regional governments have limited competences in the field of regional development and planning. This model is implemented in small member states of the European Union, especially in countries that have a one-tier system of local self-government. It is concluded that the model of local government is determined by the size of the country and the system of regional development. There are centralized, decentralized and federal models. The article analyzes the main elements of administrative management of regional planning and development in centralized and decentralized states. In the new EU Member States, the centralized model is dominant due to the smaller size of countries and the significant role of EU funds in regional development. The distribution of these resources is controlled by the central government and its agencies, but special hybrid bodies have been established in several countries. Thus, decentralization in small states was stimulated by EU funds. After the crisis of 2008, new approaches prevailed in regional development management: centralization and concentration. These trends can be seen in centralized systems, which previously partially decentralized regional development, 
so regional bodies and agencies were abolished, in regionalized countries regional units were merged, and federalization trends were suspended. In the new Member States and in the Mediterranean countries, the impact of European Union legislation is greater, as their regional units are generally less developed and are the main recipients of EU funds.

Key words: decentralization, local government, models of local government, European Union.

Значення державного управління в галузі регіонального розвитку зросло за останні десятиліття. У сучасному світі не лише національні держави, але й наднаціональна інтеграція суттєво впливають на регіональний розвиток, адже Європейський Союз став реальним актором регіональної політики. Роль наднаціональних органів, органів державного управління та місцевого самоврядування в забезпеченні регіонального розвитку стала актуальною проблемою і потребує ретельного дослідження. Феномен регіоналізму, роль $€ С$ та його стратегій регіонального розвитку активно вивчаються зарубіжними та вітчизняними вченими. Особливості місцевого управління та процедури формування місцевої політики також аналізуються науковцями, але цей аналіз здебільшого зосереджений на економіці та формуванні політики, а правове забезпечення регіонального розвитку залишається поза увагою дослідників.

Тому порівняння законодавчих норм, що регулюють вплив наднаціональних органів та органів публічної влади на регіональний розвиток, може запропонувати новий погляд на актуальну проблему. Необхідно дослідити вплив правової системи національних держав та законодавства Європейського Союзу на реалізацію місцевими органами влади своїх функцій у забезпеченні регіонального розвитку. Наше дослідження зосереджено на правовому регулюванні організації та повноважень місцевих і регіональних органів влади, тому основним завданням аналізу $\epsilon$ централізований/децентралізований підхід до регіональної та місцевої політики в національних системах. Важливим питанням $\epsilon$ визначення сутності централізації/децентралізації, адже ним визначається мета та зміст реформування системи управління регіональним розвитком. В юриспруденції централізація трактується як концепт, за допомогою якого забезпечується єдність управління [1, с. 119-121], а децентралізація, відповідно, $є$ такою системою розподілу повноважень та ресурсів, за якою більшість передається на максимально близький до споживача рівень. За традиційним підходом, централізація тісно пов'язана з реалізацією завдань центрального уряду, а децентралізація із завданнями місцевої влади. Але такий підхід $\epsilon$ проблематичним у федеративних державах, де федеральні одиниці трактуються як одиниці з ознаками державності. Тому юридично федеративні держави можуть бути централізованими, оскільки в них найважливішими суб'єктами регіонального розвитку $є$ суб'єкти-члени федерацій [2, с. 63-64]. Ці суб'єкти - наприклад, австрійські землі - інтерпретуються як субнаціональні одиниці, що мають регіональний статус, але здійснюють і центральне управління, адже мають ознаки державності. 3 погляду реалізації муніципальних завдань такі системи можна інтерпретувати як централізовані.

Відповідно до співвідношення компетенцій різних рівнів органів публічної влади щодо забезпечення регіонального розвитку виділяють три основні моделі: централізовану, децентралізовану й федеративну.

Централізована модель найчастіше реалізується в невеликих за територією країнах та базується на визначальній ролі центрального уряду та його відомств. У цій моделі місцеві та регіональні органи управління мають обмежені компетенції в галузі регіонального розвитку та планування. Хоча муніципалітети можуть виконувати важливі завдання в галузі регіонального розвитку, основна відповідальність за розроблення політики - особливо підготовка і затвердження перспективних планів та управління розподілом фондами розвитку - відбувається централізовано. Така модель реалізується в невеликих державах-членах Європейського Союзу, насамперед у країнах, які мають однорівневу систему місцевого самоврядування. 
Саме такий тип централізованої моделі склався в Словенії: країна поділена на 212 муніципалітетів, які беруть участь у прийнятті рішень щодо регіонального розвитку [3, с. 547-573], але політика регіонального розвитку належить до компетенції центрального уряду [4, с. 80]. у Словенії були організовані регіональні та субрегіональні агенції розвитку, які мають професійні офіси, що допомагають муніципалітетам у виконанні своїх завдань. Однак ці офіси можна розглядати як спеціальні органи центрального уряду. Литва та Естонія мають однорівневу систему, а отже, їхне регіональне управління централізоване, і міністерства відповідальні за регіональний розвиток та місцеве самоврядування [5, с. $162 ; 6$, с. 439]. Хоча грецькі органи місцевого самоврядування другого рівня мають кілька повноважень щодо планування, управління регіональним розвитком, воно централізовано, а розподіл коштів ЄC належить центральному уряду та його агенціям [6, с. 468-472].

Наприкінці 1990-х років склалися централізовані гібридні моделі, які засновані на централізованих національних системах, але із застосуванням планування знизу вгору. У цій моделі планування централізоване, основні рішення приймає центральний уряд. Хоча перший і другий рівень місцевого самоврядування мають певні завдання та обов'язки з планування, але на місцевому рівні організовано спеціальні гібридні органи. Таку модель раніше застосовувала Угорщина, але після прийняття Акту XXI 1996 року з питань регіонального розвитку та просторового планування завдання регіонального розвитку були делеговані спеціальним органам Радам з розвитку округу. Ці ради спочатку були тристоронніми: місцевий, центральний уряд і соціальні партнери в округах могли делегувати туди своїх членів. У 2001 р. тристоронній характер Рад з розвитку округу змінився: члени цих рад стали делегуватися центральним урядом та органами місцевого самоврядування. Цією реформою було створено 7 Рад регіонального розвитку, оскільки 19 угорських графств були органами місцевого рівня [7, с. 97-100]. Завдання органів управління виконували міністерства та агенції центрального уряду. Після муніципальної реформи 2011-2012 року ця модель була змінена на централізовану систему із запровадженням органів місцевого самоврядування другого рівня.

Чеська модель $€$ прикладом переходу до міжмуніципальної: у 2002 р. було створено 8 рад обласного рівня. Членами регіональних рад стали делегати 14-ти органів місцевого самоврядування другого рівня (повітових урядів). Регіональні ради $\epsilon$ особливими формами міжмуніципального співробітництва між органами управління та їхніми регіональними організаціями. Гібридним елементом чеської системи $\epsilon$ процедура централізованого планування та наглядові компетенції центрального уряду [8, с. 174-175]. Схожа модель розвинулась у Латвії, яка має однорівневу муніципальну систему, де Законом про регіональний розвиток 2002 р. було впроваджено спеціальні гібридні органи для регіонального розвитку [9, с. 261].

Одним із найбільш типових прикладів переходу до децентралізованої системи через міжмуніципальні асоціації $€$ Ірландія. Ірландія була в 1970-х рр. однією з найбідніших держав Західної Європи. З 1973 р., після вступу Ірландії до Європейського економічного співтовариства, ця країна отримувала значну допомогу з європейських фондів розвитку. Планування та управління розподілом коштів європейських фондів було централізовано, органи місцевої влади стали практично органами центрального уряду. Нова парадигма державного управління мала на меті децентралізувати систему: муніципалітети були зобов'язані створити Ради місцевого розвитку, які стали дієвими суб'єктами політики планування. у 2000 році були створені міські та повітові ради з питань розвитку, які стали органами місцевого самоврядування, але ними керують члени команди центрального уряду [10, с. 110-122], таким чином, ці органи $\epsilon$ гібридними утвореннями. У 1990-х роках завдяки тенденціям регіоналізації було створено два спеціальні органи: регіональні асамблеї, які практично $\epsilon$ керівними органами реалізації програм на базі Європейського фонду регіонального розвитку та Європейського соціального фонду. 
Ці органи не розглядаються як незалежний регіональний рівень: члени зборів не обираються, а делегуються муніципалітетами та повітовими і міськими радами, і вони не мають загальних повноважень на відміну від органів місцевого самоврядування [11, с. 437]. Через ці особливі характеристики вказані асамблеї можна трактувати як спеціальні міжмуніципальні асоціації органів місцевого самоврядування першого та другого рівня. Хоча планування на загальнонаціональному рівні залишається централізованим, регіональний розвиток став децентралізованим, тобто сформувалася перехідна модель, яка залишилася і після трансформації ірландської економіки.

Схожа модель склалася і в Португалії: органи управління регіональним розвитком $€$ практично міжмуніципальними об'єднаннями органів місцевого самоврядування другого рівня. Португалія не має давньої традиції міжмуніципального співробітництва, тому для планування та прийняття рішень міжмуніципальними асоціаціями були створені спеціальні кампанії. Адміністративні функції виконують компанії, що належать державним органам [12, с. 49].

У кількох країнах розподіл фондів регіонального розвитку, особливо фондів, що співфінансуються Європейським Союзом, здійснюється централізовано: центральний уряд відповідає за ці завдання, керівні органи $є$ установами центрального уряду, а регіональне планування частково централізоване. Такої моделі дотримуються країни з дворівневим місцевим самоврядуванням, але органи місцевого самоврядування другого або третього рівня мають обмежені повноваження. Таку модель реалізує Словацька Республіка, 1996 р. у 8-ми краях були створені органи місцевого самоврядування, які мають широкі повноваження. Словацькі регіони мають кілька компетенцій регіонального планування, але більшість із них належить центральному уряду та його відомствам [13, с. 289]. Так, третій рівень управління - шведські графства - мають широкі повноваження у сфері надання державних послуг, але їхні завдання дуже обмежені щодо регіонального розвитку. В останні десятиліття шведська система регіонального плану- вання стала більш децентралізованою. На децентралізацію вплинула концепція міського врядування, тому в регіональному плануванні містоорієнтовані міжмуніципальні органи відіграють значну роль.

Централізована модель базується на визначальній ролі центрального уряду, хоча органи місцевого самоврядування першого та другого рівня мають певні повноваження, основні повноваження щодо формування політики належать центральному уряду та його відомствам. у результаті реформ державного управління виконавчими органами та органами, що приймають рішення, часто $€$ компанії, що перебувають у власності державних органів. Цієї моделі дотримуються переважно малі країни з однорівневою системою та країни, які отримують значні суми з фондів ЄС. Країни, які раніше були одержувачами фінансування $\in C$ (Ірландія, Португалія), були частково децентралізовані після приєднання до Європейського Союзу і тепер вони належать до змішаної моделі. Північні країни можна трактувати як виняток із вищезазначених тенденцій: хоча їхні муніципалітети мають широкі компетенції щодо надання державних послуг, регіональні структури планування та розвитку відносно централізовані.

Децентралізована модель застосовується у великих країнах. Управління регіональним розвитком зазнало сильного впливу тенденцій регіоналізації та децентралізації в Європі. Ці тенденції мали суттєвий вплив на структуру управління регіональним розвитком. По-перше, управління розподілом ресурсами розвитку та просторове планування стали більш децентралізованими, по-друге, трансформувався регіональний рівень муніципальної системи. Система управління регіональним розвитком держав-членів Європейського Союзу зазнала впливу вказаних тенденцій по-різному. Децентралізована модель регіонального планування базується на визначальній ролі регіональних урядів. Очевидно, що національні (центральні) уряди мають компетенцію координації регіонального планування, але розподіл ресурсів регіонального розвитку та планування регіональних завдань належить до компетенції регіональних рівнів місцевого самоврядування. Тому ця модель 
тісно пов'язана з регіоналізацією, оскільки децентралізація завдань центрального уряду або концентрація завдань муніципального розвитку була одним із ключових елементів регіональних реформ. Ці регіональні реформи були різними: у ряді випадків створені квазіфедеративні одиниці, різні типи регіоналізації призвели до різних рівнів децентралізації систем регіонального планування.

Тенденція регіоналізації базувалася на створенні або посиленні місцевого самоврядування третього рівня - регіонів. Прикладом цих реформ була французька регіональна реформа, що розпочалася в 1960-х роках. Хоча феодальна Франція базувалася на регіонах, революційне та наполеонівське законодавство запровадило централізовану державу, а регіони було скасовано. Новими територіальними одиницями стали департаменти, французькі графства отримали обмеження автономії, а префект - значні наглядові повноваження. Хоча регіони як адміністративні одиниці були скасовані, регіональні відмінності залишались, і 1955 р. знову запроваджено 22 регіони, які стали частиною структури планування зверху вниз. Наступним кроком регіоналізації стало запровадження префектів регіонів у 1964 р., які отримали регіональні компетенції, тобто територіальні органи центрального уряду було частково регіоналізовано. Децентралізована модель сформувалась у результаті реформ 1982 р., коли були створені регіональні уряди як органи місцевого самоврядування третього рівня. Таким чином, у Франції існує дворівнева регіональна система управління: нижній рівень - рівень департаментів, вищий рівень - регіони. Ці регіони безпосередньо обирають раду, більшість компетенцій регіонального префекта було передано президенту обласної ради. Одним із ключових питань регіональної реформи була децентралізація компетенції планування та розвитку, адже найважливішим повноваженням регіональних префектів був розподіл ресурсів розвитку. Хоча кілька повноважень регіонального префекта залишились, але головні були децентралізовані, й тепер їх виконують регіональні ради. Регіонально-просторова структура була значно реформована за останні роки: колишні 21 материковий регіон об'єднали у 12 материкових (статус незалежного регіону Корсика та п'яти заморських регіонів залишився без змін). Повноваження регіонів були посилені цією реформою, особливо у сфері надання державних послуг. Французькі округи, департаменти втратили більшість компетенцій з розвитку, але кілька повноважень із планування залишились. у регіоналізованій французькій системі ці підрозділи $€$ основою для координації планування діяльності органів місцевого самоврядування першого рівня. Роздробленість муніципальної системи залишилася: існує понад 36500 комун - одиниць першого рівня, але реформа 1999 р. суттєво змінила їхні повноваження. Нові міжмуніципальні асоціації сконцентрували більшість місцевих повноважень з питань планування та розвитку. Таким чином, у Франції сформувалася децентралізована модель, орієнтована на регіон, де графства та місцевий уряд першого рівня мають лише часткові компетенції планування. Ця французька модель стала прикладом для Європейських регіональних реформ, особливо в тих країнах, які реалізовували французьку модель державного управління. У Німеччині Баварія має особливий статус: баварську систему можна трактувати як децентралізовану, оскільки регіональний уряд цієї землі несе головну відповідальність за регіональне планування та розвиток [14, с. 27].

Хоча кілька країн намагалися запровадити регіональні реформи на Сході, у країнах Центральної Європи єдиною успішною реформою вважають польську. Польська модель базувалася на французькій моделі децентралізації, але мала свої особливості. По-перше, польська реформа була проведена на основі злиття колишніх польських повітів, а 49 воєводств були об'єднані в 16 великих воєводств, в яких сформований третій рівень місцевої влади з широкими повноваженнями і завданнями. Дотримуючись французької моделі, рада воєводства відповідає за регіональне планування та розподіл коштів на розвиток, включаючи кошти Європейського Союзу. Органи місцевого самоврядування другого рівня (повіт) - це менші підрозділи з обмеженими компетенціями з планування. 
Місцеві муніципалітети першого рівня (гміна) мають лише завдання місцевого планування. Центральний уряд $\epsilon$ відповідальним за національні проекти та координацію політики регіонального розвитку. Польська модель $\epsilon$ децентралізованою, але центральний уряд має відносно значні повноваження в галузі регіонального планування. Таким чином, польська модель може бути інтерпретована як виняткова серед СхідноЦентральних нових держав-членів Європейського Союзу. Подібна модель склалася в Італії, яка в 19 столітті була централізованою унітарною державою, розділеною на провінції. Провінція була схожа на французький департамент, очолювалася місцевим урядом, що контролювався префектом, призначеним центральним урядом [15, с. 254]. Регіональний розвиток та планування були централізованими, провінції та муніципалітети мали лише часткові повноваження. Хоча італійська держава була централізована, регіональні відмінності залишались. Унітарний характер італійської держави зберігся, але система місцевого та регіонального управління була реформована після Другої світової війни. Водночас провінції були збережені, створені нові регіони, що стали відповідальними за регіональне планування та розвиток, володіють широкою автономією та законодавчими повноваженнями.

Можна зробити висновок, що модель місцевого управління визначається розмі- ром країни та системою регіонального розвитку. Виділяють централізовані, децентралізовані та федеральні моделі. У статті проаналізовані основні елементи адміністративного управління регіональним плануванням та розвитком у централізованих та децентралізованих державах. У нових державах-членах $\in C$ централізована модель $\epsilon$ домінуючою через менший розмір країн та значну роль фондів $\in C$ у регіональному розвитку. Розподіл цих ресурсів контролюється центральним урядом та його відомствами, але в кількох країнах сформовані спеціальні гібридні органи. Таким чином, децентралізація в невеликих за розмірами державах стимулювалася коштами фондів ЄC (Ірландії та Португалії). Після економічної кризи 2008 року в управлінні регіональним розвитком запанували нові підходи: централізація та концентрація. Ці тенденції можна спостерігати в централізованих системах, які раніше частково децентралізували регіональний розвиток, регіональні органи та агенції тут було скасовано (особливо в Греції і частково в Угорщині), у регіоналізованих країнах регіональні одиниці було об'єднано (у Франції), а тенденції федералізації було призупинено (в Іспанії та Італії). У нових державах-членах та в середземноморських країнах вплив законодавства $€ C \in$ більш значним, оскільки їхні регіональні одиниці переважно менш розвинені і $€$ основними одержувачами коштів $\in C$.

\section{ЛITEPATУPA:}

1. Kuhlmann S., Wollmann, H. Introduction to Comparative Public Administration. Cheltenham, Northampton : Edward Elgar, 2014.

2. Bäumer K. Kroës G. Decentralisation in German Context: An Assesment of Governance Actors and Approaches 'from Below'. In E. Dick, K. Gaesing, D. Inkoom and T. Kausel, eds., Decentralisation and Regional Development. Experiences and Lessons from Four Continents over Three Decades. Basel: Springer International, 2016. pp. 57-70.

3. Deželan T., Maksuti A. Uršić, M. Capacity of Local Development Planning in Slovenia: Strenghts and Weakness of Local Sustainable Development Strategies. Lex Localis - Journal of Local Self-Government, 2014. 12 (3).

4. Ravšelj D. Aristovnik A. R\&D Subsidies as Drivers of Corporate Performance in Slovenia: The Regional Perspective. DANUBE: Law and Economics Review 8 (2), 2017. pp. 79-95.

5. Adams N. National Spatial Strategies in the Baltic States. In N. Adams, J. Alden, and N. Harris, eds., Regional Development and Spatial Planning in an Enlarged European Union. Aldershot: Ashgate, 2006. pp. 155-181.

6. Measuring Regional Authority. A Postfunctionalist Theory of Governance / L. Hoogle et al. Oxford: Oxford University Press, 2016. Vol. I.

7. Pálné Kovács I. Failed Rescaling of Territorial Governance in Hungary: What Was the Gist? In S. Nunes, and J. Buček, eds., Fiscal Austerity and Innovation in Local Governance in Europe. London, New York: Routledge, 2014. pp. 95-112. 
8. Piattoni S. The Committee of the Regions: multi-level governance after enlargement. In E. Best, T. Christiansen and P. Settembri, eds., The Institutions of the Enlarged European Union. Continuity and Chang. Cheltenham, Northampton: Edward Elgar, 2008. pp. 162-182.

9. Tatham M. With, Without or Against the State? How European Regions Play the Brussels Game. Oxford: Oxford University Press, 2016.

10. Adshead M. Policy networks and sub-national government in Ireland. In M. Adshead, and M. Millar, eds., Public Administration and Public Policy in Ireland. Theory and Methods. London, New York: Routledge, 2003. pp. 108-128.

11. Callanan M. Regional Authorities and Regional Assemblies. In M. Callanan and J.F. Keogan, eds. Local Government in Ireland. Inside Out. Dublin: Institute of Public Administration, 2003. pp. 429-446.

12. Halkier H., Danson M., Damborg, C. (eds.) (1998) Regional Development Agencies in Europe. London (UK) - Philadelphia: Jessica Kingsley Publishers \& Regional Studies Associations, 1998.

13. Malíková L., Jacko T. Public Administration Reforms in Slovakia: Reviewing Previous Structures and Adopting a New Model. In S. Guérard and A. Astrauskas, eds., Local Autonomy in the 21st Century. Between Tradition and Modernisation. L'autonomie locale au XXIe siècle. Entre tradition et modernisation. Lille: Institut Universitaire Varenne, 2016. pp. 285-304.

14. Weber T., Köppert V. Kommunalrecht Bayern. 3., neu bearbeitete Auflage. Heidelberg: C. F. Müller, 2015.

15. Cassese S. Il diritto administrativo: storia e prospettive. Milano: Giuffré, 2010. 